\title{
Historical and Doctrinal Frameworks of Monastic Organization in Tibet
}

\author{
INTRODUCTION \\ The Church, yes, She must worry for She is destined not to die. Solace is \\ implicit in Her desperation. Don't you think that if now or in the future She \\ would save herself by sacrificing us She wouldn't do so? Of course She would, \\ and rightly. \\ -TOMASI Di LAMPEDUSA [1958] 2007: 29
}

Even though the position of the monastic institution within Tibetan society has changed significantly throughout the ages, there is also a distinct level of continuity. This continuity is historical as well as ideological. The way in which Vinayic literature was interpreted by monastics among the various schools has remained more or less unaltered for hundreds of years. As we are here concerned not just with monastic organization but also with attitudes of monks toward the rest of society, the manner in which certain notions seen as pivotal within Tibetan Buddhism are interpreted is also relevant. This chapter explores the historical and ideological continuations and concepts thereof discernible at Tibetan monastic institutions, for these are the building blocks of both the physical and conceptual space that the monastery occupies within society.

The earliest extant monastic guidelines stem from the late twelfth century, but according to traditional sources, monastic Buddhism was introduced in the eighth century with the completion of the monastic complex at Samyé in 779 at the behest of Trisong Detsen (Khri srong lde btsan, r. 755-797 or 755-804). Samyé was seen as the first "real" monastery in Tibet because it was a place where monks could receive ordination. During the eighth century, Tibetans who were ordained elsewhere were apparently already occupying the temples (gtsug lag khang) and other 
residences that had been built by Trisong Detsen's predecessors. ${ }^{1}$ The founding of Samyé has been viewed by Tibetans as a crucial turning point concerning the introduction of Buddhism to Tibet. ${ }^{2}$ While the introduction of Buddhism, along with writing and a legal system, during the time of Songtsen Gampo (Srong btsan sgam po, 569-649?/605-649?) was traditionally seen as a civilizing force, the construction of Samyé is thought of as an achievement that ensured the endurance of Buddhism in Tibet. This view demonstrates the widespread conflation in Tibet of religion tout court with monastic Buddhism, not unlike what occurred in other countries where monastic Buddhism flourished. Kern argues that early Indian Buddhism was primarily a monastic institution and "the laity but accessory."3 For Tibet, this conflation signifies the prominence of the monastic institution.

Another important decision, reportedly declared by the last of the Dharmarājas, Tritsuk Detsen (Khri gtsug lde btsan, a.k.a Ral pa can, r. 815-841), who promoted uniformity in Buddhist practice, was to only allow translations of the Mülasarvāstivāda vinaya and its commentaries and no other Vinaya materials. ${ }^{4}$ This sealed the fate of Tibetan monasticism, for while religious traditions quarreled over the interpretations of complex philosophical points, the shared ordination tradition brought about a more or less homogenous monastic identity among Tibetan Buddhists. This is particularly striking in comparison to other Mahāyāna countries. ${ }^{5}$

In order to understand how the monastic institutions in Tibet were managed and organized, it is useful to look at the socioeconomic status of the monasteries prior to the period under investigation, i.e., the late twelfth to mid-twentieth centuries. The Chronicles of $B a(s B a$ ' bzhed / $d B a$ ' bzhed), which should be read "as a work of historical fiction," ${ }^{\text {p }}$ provides us with clues as to how the first monastery in Tibet was perceived. The dates as well as the authorship of this text are unknown, but passages quoted elsewhere suggest that versions of this text were already in circulation by the twelfth century.7 This work tells us that, initially, Samyé was to be a temple (S. vihära, gtsug lag khang). The narrative of Samyés construction does not mention building accommodations for monks, and nowhere does it speak of Samyé as a monastery (dgon pa). However, when Samyé was completed, several people took vows there, all of whom reportedly belonged to the aristocracy. ${ }^{8}$

It is important to note that Tibetan monastic Buddhism was from the outset both patronized and controlled by the state. ${ }^{9}$ According to Monasteries of Tibet, the first monastery of Tibet was populated by over a thousand monks, not long after Trisong Detsen had founded it, and was fully supported by the state: which is to say that the ruler appointed seven families to sponsor the upkeep of one monk. ${ }^{10}$ In the beginning Samyé had no estates, no land, and no cattle. During that time all monks received the same allowances, regardless of their status: 25 measures ( $k h a l)$ of grain annually, 11 measures of butter, and 30 coins (srang). ${ }^{11}$

The widespread Tibetan narrative of the rise, apex, and subsequent decline of (monastic) Buddhism during the early transmission (snga dar) is significant for 
later conceptualizations of monastic ideals. With the completion of Samyé and the first ordinations there the introduction of Buddhism was complete, and the Sangha flourished. Being entirely dependent for its survival on the ruler as its sponsor has been idealized by many later monks as the best way to subsist. Pointing to how the first monks lived solely off the donations they received, they criticized the situation in which many a monastery found itself in later times-monks had to provide their own income by working or doing business, monasteries possessed vast estates, loaned money against interest, and invested in trade.

Although the contemporary state of monastic Buddhism is not the topic of this book, it is worth noting that because monks-both in exile and in the People's Republic of China (PRC) - have had to renegotiate their economic position in relation to both "the state" and the laity, the historical patterns that live on through shared memories play an important role in this process. In much the same vein, Aris once commented that Tibetans, "by comparison with many other peoples of the east or west, ... maintain a high level of historical consciousness and a deep sense of the vitality of the living past." ${ }^{12}$ This makes an awareness of collective memories crucial to any analysis of less ancient history as well as current affairs that concern Tibetans. It appears that in present-day China the recent increased commercialization at the monasteries is seen as problematic by monks and laypeople alike, partly because it is seen as a by-product of tourism (and state intervention) and thereby of "modern times." The collective memory here is thus rather selective, as the monasteries in traditional Tibet in fact played an active role in business. At the same time, begging laypeople for alms is nowadays regarded to be a last resort and often actively discouraged. This is not a recent development: misgivings toward (morally) coercing laypeople into giving to the monkhood are found in some of the older monastic guidelines. ${ }^{13}$

The current drive toward self-sufficiency is seen by many monks as a break from the recent past-during which the monasteries were dependent on state support-as well as a respite from the atmosphere of oppression, often associated with monastic economic policy during pre-modern times. There is the realization that self-sufficiency, by means of setting up businesses, funds, and "providing services to the community," is far from ideal, yet necessary to survive. It is clear that now for many, the purest form of monastic economy is one in which doing business is not needed and sponsors volunteer to make donations, without the monks having to ask for them. ${ }^{14}$ This is reminiscent of the earliest situation of the monastery in Tibet-or at least the collective memory of it.

There is another way in which the traditional narrative highlights the position of monastic Buddhism. For later Tibetan historians, the death of Tritsuk Detsen was followed by the disastrous rule of king Lang Darma (Glang dar ma, c. 803-842) and the subsequent period of fragmentation (sil bu'i dus). This is projected as the darkest period in the history of Tibet and Tibetan Buddhism. In the 
Tibetan histories, especially the genre of "religious histories" (chos 'byung), the collapse of the empire after the reign of Lang Darma began with the persecution of the clergy. A large portion of the monks were reportedly forced to disrobe, with some fleeing east and others west. Although it is now evident that certainly not all Buddhist practitioners left Central Tibet during that time, later narratives conflate Buddhism and monastic Buddhism, stating that only the "embers of the Dharma" were left in the region. ${ }^{15}$ This demonstrates the importance of the monkhood for the religion-for monks were seen as the keepers of the Buddha's Teachings.

Most Tibetan histories describe a period of political and social unrest following the monastic persecutions. The temples were in disrepair, the Imperial treasury was plundered, and the social order suffered the consequences. ${ }^{16}$ During this period of chaos, Tibet not only lacked a central state; social structures also had eroded. Nyangrel Nyima Özer (Nyang ral nyi ma 'od zer, 1124-1192) writes that, at that time: "A son did not listen to his father, a servant did not acknowledge his lord, and the vassal did not hear the noble." ${ }^{17}$ We now know that Buddhism had not entirely disappeared under and after Lang Darma, but rather that the monks had lost their royal patronage and that the aristocratic families were divided over the support of the religion. The accuracy of the accounts of events given in the historiographies is thus highly questionable, but for the current purpose this is irrelevant. Here it is important that this narrative was well known throughout Tibet, not just among the learned but also presumably among the ordinary people. The endurance of this semi-historical account is what Halbwachs calls "collective memory," ${ }_{18}$ explained as a group process in which the way the past relates to the present is more important than the historical facts themselves. It is likely that the Sangha's disappearance from (Central) Tibet and the social upheaval that followed were seen to be intimately related.

This pervasive narrative confirms the message that some Indic Buddhist texts are seen to convey: wherever the Sangha remains, there the Dharma will be, and where the Dharma is, the area will prosper and be at peace. The set of monastic guidelines by the Fifth Dalai Lama from 1664, for example, cites the Vinayottaragrantha: "As long as there are monks, ${ }^{19}$ the holy Dharma will remain." ${ }^{20}$ The author of these guidelines further explains: 'Because the Vinayapitaka is the foundation for all other dharmas of both Hinayāna and Mahāyāna, the Buddhist Teachings depend on the Sangha who maintain that [Vinayapitaka]." ${ }^{21}$ Very similar wording is used in the monastic guidelines for the Sakya (Sa skya) nunnery Rinchen Gang (Rin chen sgang), written in 1845 . It tells the nuns to study and practice well: "It is said that the Teachings of the Buddha depend on the Sangha." ${ }^{22}$ And again, an early twentiethcentury chayik says: "Whether or not the Buddha's Teachings remain in the world depends on the Sangha that maintains them." ${ }^{23}$ This demonstrates an awareness that the Sangha had as its primary role the preservation of the Dharma, making "concern for the happiness of all beings . . the foundation of the Sangha's very existence,"24 
but only implicitly: the methods to bring about lasting happiness (i.e., nirvāna) are the Buddhist Teachings that the spiritual community is charged with continuing. ${ }^{25}$

Connected with this responsibility to preserve Buddhism is the notion of what is often translated as the "degenerate times," the kaliyuga (snyigs ma'i dus). ${ }^{26}$ This age of decline implies not only that Buddhism as we know it will one day disappear, but also that before its disappearance it will gradually become more difficult to properly practice. Monks, in particular those who have studied the Vinaya, display an acute awareness of this notion. Some use it to explain the divergence between the original Vinaya rules and the practice found among Tibetan monks: "In this day and age we cannot keep the Vinaya in all its details; this is because of the degenerate times (snyigs dus). But we keep the rules as well as we can. The monastic guidelines are written in accordance with the times; these rules are generally more relaxed than the exact stipulations in the Vinaya." ${ }^{27}$ The abbot of the nunnery Genden Chöling (dGe ldan chos gling) in India mentions that this allowance for relaxations in the discipline can be found in the Vinaya itself. Here, he may be referring to the exemptions with regard to monastic communities living in the outer regions mentioned in the Vinaya. ${ }^{28}$

One senior monk I interviewed complained that whenever he commented on the lax attitude toward discipline at his monastery, monks commonly retorted: "Oh well, considering the times ....," implying that when one takes the current age into account, the monks look good in comparison. ${ }^{29}$ This notion of the age of decline was also seen in the past as a valid reason to relax the rules, ${ }^{30}$ which affected both the internal organization of the monasteries as well as the way in which monks dealt with the outside world. The monastic guidelines themselves regularly claim that they contain rules that are adapted to the specific place and time, thereby appealing to a mind-set common among monks.

The Sangha, synonymous to most ordinary people with "monks" (and only rarely with "nuns"), did not exist simply in order for the laypeople to gain merit. Similarly, monks were not there solely to perform rituals to appease local spirits on behalf of the ordinary population. Their role was more substantial. Although perhaps not during the initial stages of the introduction of monastic Buddhism, but certainly from the eleventh century onward, monks in Central Tibet started to play a bigger role and were classed among the "important men" (mi chen po). According to Davidson, the efforts of these important people to spread the Dharma "were understood as contributing to social cohesiveness and organizations, a trend in Tibetan public life that continues to the present." ${ }^{31}$ Their presence alone furthermore provided a shared identity: "Buddhism had always been seen as the core of Tibetan identity, and its clergy the epitome of "Tibetanness." 32 The importance of the Sangha, the monks in Tibetan society, cannot be overemphasized. Their primary position-collectively, though not always individually-should be kept in mind when discussing the societal role of the monastery and the monks. 
Yet another aspect of Tibetan monastic Buddhism is its portrayal as the embodiment of the continuity of the Indian tradition. The notion of the necessity for unbroken lineages of practice, ritual, and ordination brings with it a notoriously conservative attitude and an aversion toward innovation and invention. Kapstein sees the ideology of monastic Buddhism in Tibet as one "that often appears to systematically devalue innovation and personal inventiveness, considering them sources of deviation and of the transgression of the genius of the past." 33 This is particularly well attested in the Tibetan scholastic tradition, in which accusations that an individual writer was being imaginative, creative, or promoting divergent ideas-all possible translations of rang bzo-were particularly damaging to one's scholarly reputation. ${ }^{34}$

Although current scholars acknowledge that the Tibetan variety of Buddhism is most definitely not a carbon copy of the "original" Indian religion and that it was adapted in many ways, ${ }^{35}$ the fact remains that the complete preservation of the religion and its accompanying rituals has been idealized among monks. Changeany change-may have been seen as possibly disrupting the process of preservation. This conservative attitude with regard to matters of religion is likely to have affected the behavior of monks within social settings. Furthermore, this type of "inertia, or conservatism, may cause cultural forms to persist, perhaps even for centuries, while material conditions are changing." ${ }^{6}$ There are other factors that contributed to this conservatism-or fear of change-and the subsequent statusquo attitude among the monastic agents, which in turn affected the relationship between monks and laity. ${ }^{37}$

Another significant feature of Buddhism in Tibet is that it held a monopoly position. Although there were several schools that sometimes vied for disciples and sponsors, and fought over doctrinal issues and transmission lineages, monks were, generally speaking, united in their vows. Of course the presence of the Bon religion cannot be denied, but in the longue durée of Tibetan history its adherents played only a minor role in the public sphere. What was then the impact of this monopoly position? According to market theory, a monopoly position of a product or a service is expected to decrease social welfare. ${ }^{38}$ This monopoly in the religious market is then seen to reduce the level of morality of individual believers, but to "improve the quality of the moral constitution supporting a market society." ${ }^{39}$ In other words, a shared religion brings about shared values, which positively influence society. This is why it has been argued that a monopoly in the market for organized religion could in fact increase the "net social welfare." ${ }^{\circ}$ This contemporary argument would not look amiss in the writings of pre-modern Tibetan monastics, although this type of reasoning is rarely explicitly present in the monastic guidelines.

The central role of monastic Buddhism in Tibetan society, the need for the preservation of the religion, the degenerate times, the conservative attitudes, and 
the religious monopoly position all emphasize both the centrality and continuity of Tibetan monasticism. At the same time, living in the kaliyuga meant that potential threats and evils had to be regularly negotiated, indicating change as well as continuity. This continuity makes it possible to look at Tibetan monasticism diachronically and to detect certain patterns. By uncovering these patterns, one may identify changes over the centuries, and the factors that led to those changes.

\section{THE INFLUENCE OF BUDDHIST LEARNING ON MONASTIC ORGANIZATION}

One of the factors that encouraged continuity and homogeneity among monks and, less overtly, even among laypeople is "the Buddhist Weltbild." What did people actually know about Buddhism? We first must acknowledge that the level of education-and this includes formal religious education-was relatively low at the monasteries. Among the population of Drepung, for example, it is estimated that ten percent were scholar monks ( $d p e$ cha $b a$ ). ${ }^{41}$ These monks at the larger university-like monasteries studied topics that were often highly abstract and philosophical. Works that are now seen as primary texts containing "basic Buddhist values," such as Tsongkhapa's Stages of the Path to Enlightenment (Byang chub lam gyi rim pa), Atiśa's Lamp for the Path to Enlightenment (Byang chub lam gyi sgron me), Gampopa's Precious Ornament of Liberation (Rin chen thar rgyan), and Patrul Rinpoche's Words of My Perfect Teacher (Kun bzang bla ma’i zhal lung), do not appear to have been part of the general curriculum at most monasteries. These texts were taught-if at all-at public venues, where laypeople and monks gathered to listen to a sermon by a great master. Perhaps the main exception is Sāntideva's Bodhicaryāvatāra (sPyod 'jug), a text widely studied in centers of Nyingma scholasticism. ${ }^{42}$ This leaves us to ask what the monks actually learned and thus knew about Buddhism and about what may now be called "Buddhist ethics." This subject has not been widely studied, perhaps partly because the results of a query into this matter would necessarily be highly speculative. For the current purpose it is important to understand the kind of religious education that monks with positions of power and influence received.

In the Ratnarāsisūtra, the Buddha tells Kāśyapa that an administrative monk ${ }^{43}$ should be either an arhat, or someone who "is purified, who is fearful of censure in the other world, who has confidence [in the idea that results will come about for him as] the maturation of [his own] deeds, and who feels shame and remorse." ${ }^{4}$ In other words, he should be a person who has a deep understanding of karma and who knows how to apply that understanding to his own actions. Most of the Tibetan monastic guidelines take a more pragmatic stance with regard to the religious accomplishments of monks in charge of administrative or managerial tasks. The monastic guidelines for Tashi Lhunpo state that a prospective candidate for 
the position of disciplinarian needed to have a better standard of education. ${ }^{45}$ This was not the only requirement: one also had to be affluent, of an authentic lineage, ${ }^{46}$ and have an imposing physical appearance. ${ }^{47}$

In the Nyingma monastery Pelyul in Kham, certain important positions, such as that of the great chant master ${ }^{48}$ required someone who had completed a threeyear retreat. If no one of that rank was available, the individual still had to be from the ranks of monks who had completed various other types of retreats. ${ }^{49}$ The source for this information is a monk who lived at that monastery before the 1950s. The extant set of monastic guidelines unfortunately does not give this type of information.

It appears that in the past in Geluk monasteries it was unusual for people with a geshé (dge bshes) title, the highest educational degree, to fill administrative positions..$^{50}$ In Sakya monastery, however, "a doctor of theology" ${ }^{51}$ regularly was appointed to a high managerial position at the Sakya estate (zhabs pad)..$^{52} \mathrm{To}$ become a disciplinarian there during the late 1950s one had to have followed the monastic curriculum up to a certain point, but it was not essential to be a dge slong. ${ }^{53}$ Whatever the level of education of monastic decision-makers, the monastic education system itself was clearly not designed to teach "applied Buddhism." Wangchuk mentions that the monastic system expects educated monks to master three activities, namely teaching, debating, and composing. In this way, the monks preserve and spread the Buddhist Teachings and work for the well-being of other living beings. Wangchuk hypothesizes that because helping others is done solely on the basis of the knowledge gained from their education, the educated monks are traditionally not primarily charitable or socially engaged, and that this may be the reason that there are very few charitable undertakings in Tibetan society. ${ }^{54}$

\section{SOCIAL REALITIES AND BUDDHIST THOUGHT}

"Buddhist traditions generally did not develop practical ethical systems which might work to ameliorate the genuine suffering of the world." 55 At least, not in the way current nongovernmental organizations and the like try make the world a better place. In Tibetan Buddhist literature, social realities are not often reflected or commented upon. When this does occur, it seems that these realities, such as the plight of those who transport tea to Tibet, ${ }^{56}$ or the hypocrisy of those Tibetans who purport to be pious but crave meat excessively, are highlighted not in order to encourage direct change, but to show the realities of samsanra and thereby the need to renounce concerns for the current life alone. The aim of these types of texts is to show the "injustice" of certain common situations, so as to provoke the realization that cyclic existence does not provide a stable base for any type of well-being, which includes justice. Emphasizing human (and other) suffering was thus usually not directly aimed at mustering support to rally against social injustices. 
Similar topics that can be recognized as relevant to social welfare are mentioned in religious texts when authors write about compassion. The audience is reminded of the suffering of sentient beings, of the poverty and disease of a stricken populace. The aim is to evoke not only feelings of compassion but also a heartfelt commitment to do something about the suffering of others. This commitment, however, does not translate into social action-or at least, social action is not presented as a necessary expression of this commitment. This is because of the strong awareness that an ordinary human being is unable to structurally alter the plight of others: only a Buddha can. ${ }^{57}$ In this way, the attainment of Buddhahood becomes the ultimate goal. Nonetheless, for those committed to the goal of attaining enlightenment for the sake of fellow beings, helping others is presented as a responsibility, as well as a necessary means to accumulate the merit required for the achievement of that goal.

According to the Buddhist doctrine in the Tibetan tradition, understanding the world around us, understanding the unjust and dissatisfactory nature of samsāra, is necessary to arrive at those most essential of Mahāyāna Buddhist concepts: renunciation (nges 'byung gi bsam pa) and the wish to attain enlightenment (S. bodhicitta, byang chub kyi sems). For Buddhist practitioners a thorough awareness of the outside realities is therefore warranted, although it is likely that a rather abstract and general understanding of those realities was seen to suffice for most. In fact, meditation was in some cases preferred to directly aiding others. The Kadam master Geshé Tönpa (dGe bshes ston pa, c. 1004/5-1064) was reportedly asked whether it is better to practice in solitude or to help beings by means of Dharma. He replied: "In this current age of decline, it is not the time for an ordinary being to actually help others, while not being involved in developing love, compassion, and bodhicitta in solitude. ${ }^{58}$ Thus in degenerate times, practice takes priority over venturing forth to help others.

Traditionally then, the focus on love, compassion, and the resolve to attain enlightenment served first and foremost to change the practitioner's mental attitude and did not appear to have resulted in a push for a structured change of the status quo. To wit, neither secular nor religious institutions in pre-modern Tibet facilitated such undertakings, at least not structurally. Social and economic mobility was limited within the strongly hierarchical Tibetan society. This societal rigidity was in part due to "collective conservatism," which was maintained for a variety of reasons. The influence of the Buddhist Weltbild maintained by Tibetan believers - and thereby social agents-should also not be underestimated.

Psychological research on the concept of justice among young monks in a contemporary Tibetan Buddhist monastic community in Nepal suggests:

The virtues of liberty, equality, and justice are not emphasized in this particular Buddhist environment. Concern for compassion and suffering takes absolute precedence. Perhaps in a worldview where fairness is built into the fabric of the uni- 
verse (the concept of karma) one need not be preoccupied with making the world fair or just. ${ }^{59}$

This initially confirms that there are certain issues that take center stage in textual Buddhism and become incorporated in the mind-set of monks. Speculative as the above-cited research may be, it strengthens the hypothesis that doctrinal discussions of (human) suffering were not primarily geared toward, and usually did not lead to, social engagement. In the words of Spiro: "soteriological action provides no support for action in this world. As it is nirvana through knowledge, not through works."6o

\section{THE MONASTERY AS A CORPORATE INSTITUTION}

Economic historians have described the medieval Catholic Church as a corporation closely connected to economic progress. Weberians have argued that the Church was responsible for slowing down economic development in Europe, whereas others have argued that the Church had a positive influence on economic growth. ${ }^{61}$ It is less common to analyze Buddhist institutions in such a way. ${ }^{62}$ Considering Buddhist monasticism in China, Walsh defines an institution as "a competitive structure seeking to perpetuate itself." He argues that religious institutions such as monasteries operate as corporate bodies. ${ }^{63}$ Miller, who surveyed Tibetan monastic economy, disagrees with this notion of an institution and sees the monastery "as a collection of individuals having individual, transient funds." ${ }^{4}$ Indeed, when considering the Tibetan case, it is unlikely that monks ever thought of their monastery as an economic unit (which does not mean that it was not one). However, the stress Miller lays on the individuality of the monks also seems unwarranted. Still, it is often claimed that there is a high degree of individualism in Tibetan Buddhism. ${ }^{65}$

This emphasis on the individual has its precedence in the depiction of Indian Buddhism. Dumont, in his Homo Hierarchicus, writes: "Buddhism truly expresses the place of the individual in Indian Society." ${ }^{36}$ As argued above, the Tibetan Buddhist monastery as an institution is generally not concerned with salvation or liberation, but with continuation and preservation. In that way the monastery's task is to preserve the facilitation of salvation on an individual level. This is what gives monks their individuality: they, at least in theory, have the individual choice to make use of the facilities.

Goldstein claims that "the karma-grounded ideology of Tibetan Buddhism saw the enforcement of morality and values as an individual rather than an institutional responsibility." ${ }^{67}$ This statement is perhaps only partially correct, for it is true that in the monastery orthopraxy is more important than orthodoxy, ${ }^{68}$ but the contents of the monastic guidelines demonstrate that this can never have been entirely the case. These texts show us that the (publicly displayed) lax morality of 
a few monks would reflect negatively on the whole of the Sangha: firstly, because it would inspire bad behavior in other monks, and secondly, because it would cause the laity to lose faith in the Sangha. This made morality-at least to the extent that it pertained to external behavior-an institutional concern. This concern is highlighted in the monastic guidelines, which compare the danger of harboring a single individual with faulty discipline to the presence of one diseased frog in the pond, potentially infecting all the other frogs. ${ }^{69}$

In most other contexts, it appears that the word "individuality" to describe the lifestyle of monks is misguided, for it bears too many (both Western and modern) connotations that are simply unheard of in a monastic setting, even today. The nature of the monastery as an institution is that of a conglomerate of individuals, each of whom to a large extent retains the socioeconomic status he held in the "lay world." At the same time, they form a socioeconomic unit. The monastic guidelines paint a picture of a monastery as a socioeconomic unit, while acknowledging that individuals are the parts who create the whole. When viewing the monastic guidelines from the point of view of their audience, one finds that they both address the whole (how the monastery ideally should function) as well as the parts (the role individual monks play within the institution).

According to Collins, what monasteries intend to be is not always what they then turn out to be:

Although it seems that both Buddhist and Christian monasticism aims to incarnate the close sense of community which sociologists often call Gemeinschaft, that is a small group with close cohesion, emotional intensity and absence of internal division, it is more likely that the monastic group is a Gesellschaft, a society with separate and separable individuals whose relations are governed by contract and whose ultimate goal lies beyond the immediate fact of association. ${ }^{70}$

When it concerns Tibetan monasteries, it seems more likely that the monastic institution is both a group with close cohesion and a society with separable individuals governed by contract. This is particularly evident in the larger monasteries, where the internal cohesion is found largely within the separate monastic houses ${ }^{71}$ or colleges, whereas solidarity between these houses and colleges was far more tenuous. ${ }^{72}$ More generally, the monastic guidelines see a good reputation among laypeople, religious prestige, a steady flow of donations, a stable community of monks, and a conducive political climate as vital to the continuation of a monastic institution. None of these are issues entirely beyond the reach of the monastery.

Justification for Buddhist monasteries holding important positions of power in Tibetan society was found in the doctrinally prevalent notion of the paramount importance of preserving the Sangha: the end justified the means. Viewing the monastic institution as a corporation, in which monastic agents act on (at least) two levels, namely individual and communal, allows one to understand how certain types of behavior that would be unacceptable if they concerned a lone monk 
would be allowed or even encouraged if the whole community could benefit from them. This bipartite modus of organizing the community is not just an aspect of Tibetan monasticism, but is present in Indic Buddhist texts as well. ${ }^{73}$ In Buddhist India, for example, the offerings given to a stūpa could not be redirected to the general nor to the universal community (i.e., the monks present locally and the entire Sangha, respectively)..$^{74}$ This clearly demarcated division is also apparent in the Vinaya literature, which demonstrates that the monastic community is not in itself liable for the actions of its members. Schopen gives the example of debts left by deceased monks: the debtors had to consider their money lost..$^{75}$ This is another instance-and there are many-in which the monastic institution is comparable to a modern-day corporation.

For Ashman and Winstanley, contemporary corporations exist "as legal and economic entities constructed to pursue social and economic objectives." ${ }^{76}$ The Buddhist monastery does not fit this definition, for its fundamental aim is the betterment of all beings, and more specifically, the continuation of the Dharma. Contrary to what is claimed by some, I do not believe that the Sangha's primary aim is to "raise the efficiency of religious practice" and that "its beneficiaries are none other than the monks who constitute its membership." 77 Aside from having social and economic objectives, the monastery does have features akin to those of corporations. One such feature is corporate identity. Corporate identity is similar to monastic identity, which is imbued with the notion of belonging to a larger community that has a shared purpose and a sense of belonging.

It is problematic to view the corporation-not an actual entity-"as possessing identity or acting as a conscious moral agent." ${ }^{38}$ Velasquez questions the notion that a corporate organization can be held morally responsible (at least in part) for its actions, and dismisses the idea that there is such a thing as corporate moral responsibility. ${ }^{79}$ Modern-day lawmakers appear to be in accordance with Velasquez, as they seem to acknowledge that only individuals can be ascribed morality, and thereby culpability. ${ }^{80}$ To translate this into Buddhist concepts: just as a corporation cannot be held morally responsible, it also cannot accumulate karma-only individual agents can. What monks did on behalf of the monastic administration, with a benevolent motivation, would not have been seen as reprehensible in any way, regardless of the consequences of those actions. This in turn is a partial explanation for the relatively low level of social responsibility that monasteries appear to have had for their immediate surroundings.

This is by no means to suggest that monastic institutions acted with impunity. Despite the fact that "the moral order of organizations has a powerful effect on individual motivation, morale and performance," ${ }^{, 1}$ the monasteries were ruled and administered by individuals, usually monks, who had their own sets of values. The religious figures of authority, portrayed in hagiographies, are often depicted as being heavily involved with "serving social ends," of which the bridge-builder 
Tangtong Gyelpo (Thang stong rgyal po, 1385-1464) is a famous example. Helping others, however, took place on an individual basis. ${ }^{82}$ Presumably, members of the monastery did see themselves as having a certain responsibility regarding the lives of others. However, this generally did not translate into the improvement of the socioeconomic state of others but rather in the facilitation of religious practice and merit-making. Clearly, in Tibet the relationship between the monastery and the laity was not limited to mere religious facilitation. It was much more far-reaching. When this relationship is examined, in particular with regard to the perceived religious responsibilities and justifications of certain socioeconomic practices, a clearer picture of the social embedding and role of monastic Buddhism as practiced emerges.

To move beyond the simplified, yet valuable, model of the bipartite levels of perceived moral responsibility, one needs to look at the monastic organization, the roles the individuals played within it, and the Buddhist values embedded within this larger corporation. By understanding the day-to-day organization of the monastery it becomes easier to answer fundamental questions such as whether monasteries actually forced laypeople to work for them or whether it was seen as a meritorious exchange. It also helps to comprehend the rights and duties ascribed to laypeople and monks, both materially and religiously. By understanding the underlying Buddhist frameworks, combined with the way in which the monasteries were organized, it becomes possible to gain a more nuanced picture of the extent and nature of social responsibility among monks and monasteries in traditional Tibet. 